\title{
EVALUATION OF FRUŠKA GORA NATIONAL PARK (SERBIA) FOR SPORT AND RECREATIONAL TOURISM
}

Aleksandra Vujko, Jovan Plavša

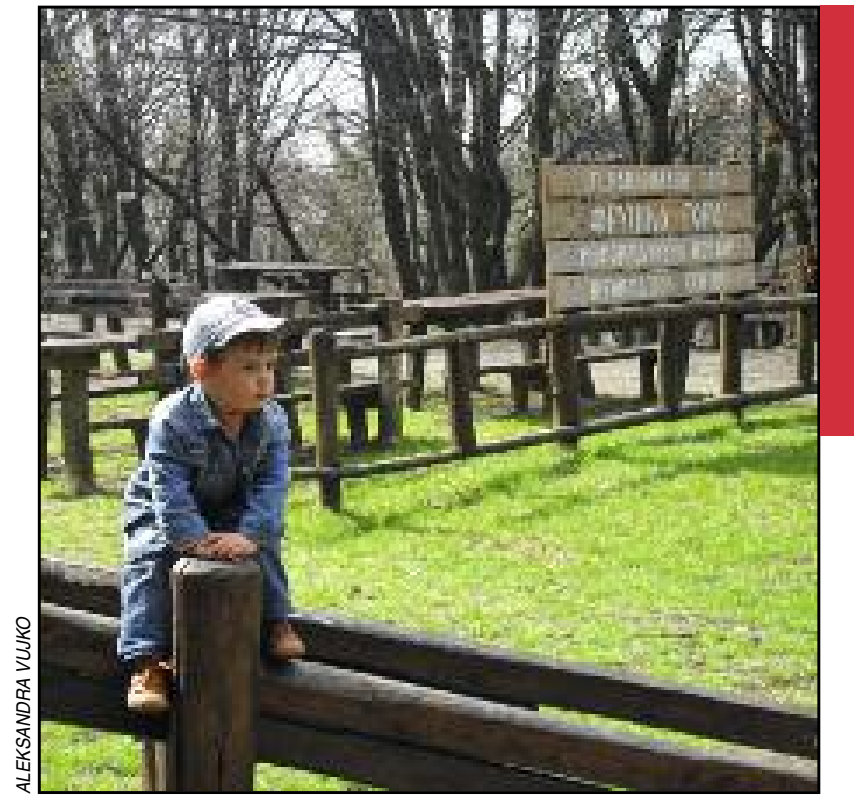

Fruška Gora National Park is one of the most attractive areas for sport and recreational tourism. 


\section{Evaluation of Fruška Gora National Park (Serbia) for sport and recreational tourism}

DOI: http://dx.doi.org/10.3986/AGS54206

UDC: 712.2(497.11-751.2)

COBISS: 1.01

ABSTRACT: The Fruška Gora National Park has one of the biggest sport and recreational potentials in Vojvodina, Serbia. Because of its favorable natural and geographical features Fruška Gora National Park. Since sports and recreational tourism is of growing importance in the tourism industry, the evaluation method to create a high quality tourism product becomes inevitable. Empirical research conducted on a sample of 304 respondents was aimed at showing the existing potentials of Fruška Gora National Park related to sport and recreational tourism. The interviews with experts from the Provincial Secretariat for Environmental Protection, the National Park and the Cycling Association of Vojvodina helped the SWOT analysis of sport and recreational tourism on Fruška Gora National Park.

KEY WORDS: geography, tourism, tourist evaluation, sport and recreational tourism, Fruška Gora national park, Vojvodina, Serbia

The article was submitted for publication on August 12, 2011.

\section{ADDRESSES:}

Aleksandra Vujko, Ph. D.

Faculty of Science, University of Novi Sad,

Trg Dositeja Obradovića 3, 21000 Novi Sad, Vojvodina (Serbia)

E-mail: aleksandravujko@yahoo.com

Jovan Plavša, Ph. D.

Faculty of Science, University of Novi Sad,

Trg Dositeja Obradovića 3, 21000 Novi Sad, Vojvodina (Serbia)

E-mail: pivoljak@yahoo.com 


\section{Introduction}

Sport and recreational tourism has become a very attractive form of tourism that attracts millions of direct respondents. Whether it is a competitive sport (professional or amateur), extreme or recreational, its role in tourism can be of great importance (Standeven and De Knop 1999; Plavša 2007; Papadimitrou and Gibson 2008; Weed 2008; Vujko and Tomka 2009; Vujko and Plavša 2010; Vujko 2011). Looking at sport and recreational tourism in the context of a healthy lifestyle, active rest and recreation, various programmes that contribute to the development of sport and recreational tourism and tourist destinations are perceived. Natural and geographical features of the Mountain are very good for sport and recreational tourism. Fruška Gora is located in the northern part of Srem (South-western Vojvodina). It has a total surface area of $21,500 \mathrm{~km}^{2}$, which makes $24.3 \%$ of the whole territory of the Republic of Serbia (Đurđev et al. 2010). Since this part of Vojvodina is situated between the Danube and the Sava rivers, this means that Fruška Gora Mountain is situated in Srem, mostly in Serbia, with only a small part, in the far west, situated in Croatia (Bukurov 1978). Mountain is an interesting area for development of cycling tourism in Vojvodina. In its west-east direction it has the length of about $80 \mathrm{~km}$. This low island type mountain, with the peaks Crveni čot $(539 \mathrm{~m})$, Orlovac $(512 \mathrm{~m})$, and Iriški venac $(490 \mathrm{~m})$, represents a mountain with a special benefit for the development of sport and recreational tourism (Jovičić 1962; Milić 1973; Ahmetović - Tomka 1995).

The central part of the Mountain has the shape of a long anticline (Petković et al. 1976), east-west, with a fragmented appearance of the wings and partial phishing. Anticline is symmetrically preserved, except in the far eastern part where it sank beneath the northern flank of the Danube fault (Petković et al. 1976). The Mountain base is surrounded by two loess plateau areas, $130-150 \mathrm{~m}$ and $110-120 \mathrm{~m}$ high. The Mountain is partly covered with thick or thin layers of loess and loess deposits that ease severity and sudden transitions that are characteristics of older and more compact rocks, which is certainly in favour of sport and recreational tourism as a viable and accessible mountain in almost all its parts (Petković et al. 1976; Dragutinović 2000; Obradović 2006). However, to give an objective appraisal of the elements of Fruška Gora National Park sport and recreational tourism potential (individually and collectively), and to determine its usefulness and exchange value, it was necessary to access the tourist evaluation because evaluation means conscious development of tourism in a destination (Ćurčić and Bjeljac; Reynard and Fontana 2007; Pereira et al. 2007; Comanescu et al. 2009).

The aim of the research is to show the potential of the Fruška Gora National Park for sport and recreational tourism with method of evaluation individual natural and cultural sites. The purpose of this paper is to determine the value and tourist attraction of sport and recreational tourism, by means of quantitative and qualitative methods of tourism evaluation (Čomić and Pjevač 1997) and methods set by Hilary du Cros (du Cros 2001), modified by Olga Hadžić and her associates (Hadžić et al. 2010).

\section{Metodology}

The starting point of the research was a group of variables concerning natural and geographic tendencies of Fruška Gora National Park for sport and recreational tourism. Total number of respondents was 226 in the area of Novi Sad and 78 respondents from seven different places near the mountain (Petrovaradin, Sremska Kamenica, Sremski Karlovci, Banstol, Čortanovci, Ledinci i Erdevik). Two sets of variables with the aim of checking the respondents' attitudes about potentials of the Fruška Gora National Park for sport and recreational tourism were used.

The first group of variables was about the opinions on suitability of the mountain area for development of sport and recreational tourism. The second group of variables interviewed about the names of those areas.

The data were processed by appropriate statistical methods of descriptive and comparative type, which enabled explanation of research results and reaching conclusions. Bearing in mind that the obtained data confirm the preliminary hypothesis that the Fruška Gora National Park is a suitable area for development of sport and recreational tourism, it was necessary to move to the next step in the in the research, tourist evaluation of the area. This kind of development is in favour of regional (business and economic, ecological and sustainable) development (Serrano and Gonzales-Trueba 2005; Pralong 2005; Pereira et al. 2007; Reynard and Fontana 2007; Erhartič 2010). 
Benefits from the development of sports and recreational tourism would be more far-reaching leading to development of natural and cultural resources (Standeven and Knop, 1999; Cutumisu and Cottrell, 2004, Vujko, 2012).

Two methods were used in the process of tourism evaluation of Fruška Gora Mountain. The quantitative-qualitative method is frequently used because it allows great freedom in both research and assessments (Čomić and Pjevač 1997). The more complex one was set by Hilary du Cros (du Cros 2001), and modified by Olga Hadžić and her associates (Hadžić et al. 2010). This method is considered to be more reliable, and therefore scientifically suitable. To be accepted as a valid method in assessing the natural and cultural values relevant to sport and recreational tourism in the Fruška Gora National Park, it was necessary to involve experts from sports and recreational tourism. Each site was evaluated by two grades. The upper part of the evaluation consists of the average grade obtained from the following experts: Nebojša Subić, President of Cycling Association of Vojvodina and Milivoj Kišdobranski, the organizers of Sunday's action »Pawns in nature« and one of the founders of »Fruškogorski marathon«. The lower part of the assessment was obtained from one of the authors, namely Aleksandra Vujko.

The main elements of tourist evaluation were: accessibility of resources, tourist services and equipment (existing storage capacity, complementary tourist offer and tourist-information services, marketing, etc.), environment (natural and built), specific resources, the importance of resources (depending on their impact on market and well knownness), and artistic value (Čomić and Pjevač 1997; du Cros 2001; Hadžić et al. 2010).

The proposal of locality given on the map was the result of a field research (the results of field research carried out in an extensive research project have been used (Vujko 2011). The maps were drawn by internet software Geokarta.

\section{Results and discussion}

Sport and recreational tourism can be developed on the Fruška Gora National Park in various forms, in accordance to the position, basic characteristics of the terrain, climate characteristics, hydrographic network and biodiversity. Moreover, all types of sport and recreational tourism can be developed: recreational (all routes within Fruška Gora), event based, sport and recreational tourism and extreme sport and recreational tourism since the inside paths of Fruška Gora Mountain are very demanding terrain by their physical characteristics. The most interesting and economically advantageous period for sport and recreational tourism is from March to October. Bearing all this in mind we can conclude that the information obtained from the research was in concordance with the potential of the mountain. In support of the Fruška Gora National Park is just the absolute altitude and terrain mobility. Mountains up to $600 \mathrm{~m}$ above sea level are suitable for diabetics, stenocardia, nervous tension, respiratory, and recovery after a heart attack. These mountains are also called »air spas« (Stanković 1994). The most important question in the first group of

Figure 1. Possibility of the Fruška Gora National Park for development of sport and recreational tourism $(\mathrm{N}=221)$.

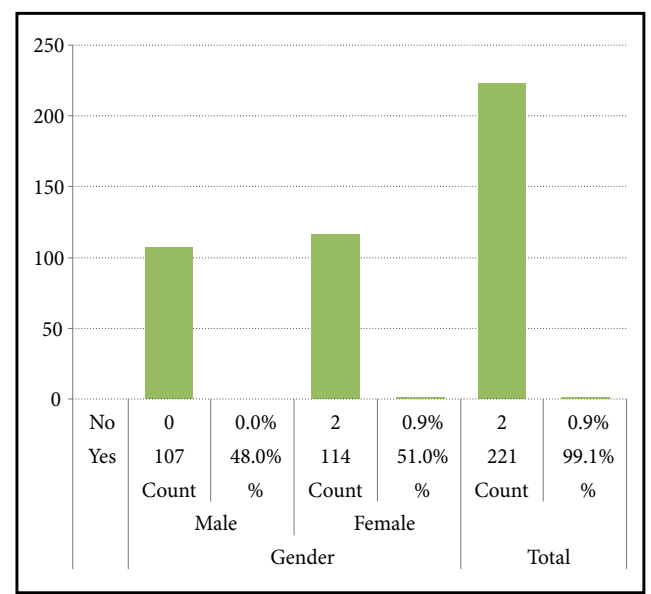




variables is related to whether respondents feel that the Fruška Gora National Park is a suitable area for development of sport and recreational tourism.

Of total number of respondents (226) from Novi Sad, even 221 (99.1\%) thought that Fruška Gora National Park is suitable area for development of sport and recreational tourism, which can be seen in Table 1 and Figure 1. Regarding the age structure of the respondents from the mountain area (Table 2) survey included $59.0 \%$ males and $41.0 \%$ females. The largest percentage of them $24.4 \%$ was from Petrovaradin, followed by $19.2 \%$ from Sremski Karlovci, $17.9 \%$ from Čortanovci, 6.4\% from Banstol, 7.7\% from Erdevik, 11.5\% from Sremska Kamenica and 12.8\% from Ledinci.

The respondents of both genders disregarding their place of residence almost unanimously agreed that the Fruška Gora National Park is a suitable area for development of sport and recreational tourism, followed by the issues of patients required to nominate areas that they think were the most suitable destination for sports and recreational tourism. Total number of respondents who answered this question was 174 in the area of Novi Sad (Tables 4, Figure 2 and Figure 3). 118 respondents (67.82\%) have the opinion that the territory of the whole mountain is the suitable area for the development of sport and recreational tourism; whereas only 15 respondents (8.62\%), responded to this question with I do not know.

Table 3: Areas suitable for development of sport and recreational tourism in the Fruška Gora National Park by the opinion of participants, depending on the sex of participants.

\begin{tabular}{|c|c|c|c|c|}
\hline \multicolumn{2}{|c|}{ The answers given by the participants } & \multicolumn{2}{|c|}{ Gender of participants } & \multirow[t]{2}{*}{ Total } \\
\hline & & male & female & \\
\hline Which areas in the Fruška & All & 53 & 65 & 118 \\
\hline Gora National Park & I do not know & 6 & 9 & 15 \\
\hline can contribute to the & Around the lakes & 4 & 1 & 5 \\
\hline development of sport & Stražilovo picnic area & 0 & 2 & 2 \\
\hline \multirow[t]{19}{*}{ and recreational tourism? } & Popovica and Iriški venac picnic areas & 0 & 1 & 1 \\
\hline & Popovica picnic area & 0 & 1 & 1 \\
\hline & Around the lakes and picnic areas & 4 & 0 & 4 \\
\hline & Along The Partisan way & 1 & 0 & 1 \\
\hline & Danubean part of Fruška Gora Mountain & 1 & 0 & 1 \\
\hline & Letenka picnic area & 2 & 0 & 2 \\
\hline & Areas that are not populated & 1 & 0 & 1 \\
\hline & Brankovac and Osovlje picnic areas & 0 & 1 & 1 \\
\hline & Stražilovo, Popovica and Glavica picnic areas & 2 & 0 & 2 \\
\hline & Andrevlje picnic area & 1 & 0 & 1 \\
\hline & The central part of Fruška Gora Mountain & 0 & 1 & 1 \\
\hline & Picnic areas & 5 & 2 & 7 \\
\hline & Testera picnic area & 1 & 0 & 1 \\
\hline & Letenka, Stražilovo and Banstol picnic areas & 0 & 1 & 1 \\
\hline & Ledinci village & 0 & 1 & 1 \\
\hline & All marked paths & 1 & 1 & 2 \\
\hline & Šakotinac lake & 1 & 2 & 3 \\
\hline & Spas in Vrdnik, Erdevik and Ljuba villages & 1 & 0 & 1 \\
\hline & Iriški venac and Thermal Spa in Vrdnik village & 1 & 1 & 2 \\
\hline \multicolumn{2}{|l|}{ Total: } & 85 & 89 & 174 \\
\hline
\end{tabular}

Sport and recreation operate successfully in the prevention of the typical diseases of modern civilization, visible as a neurosis due to various tensions, urban noise, air pollution (Simonsen et al. 1998). Based on similar evaluation that were carried out on natural sites (Pereira et al. 2007; Comanescu et al. 2009) in continuation of work to approach the evaluation of the Fruška Gora National Park on the basis of methods used for evaluation. According to the qualitative-quantitative method, first the nature and geographical areas and their association with sport and recreational tourism were analysed. Table 4 and figures (Figure 3 , 4 and 5) show the lowest grades for accessibility (most sites are not marked), and travel equipment.

What represents the highest potential when natural and geographic areas are in question are high grades for atmosphere, the specific resources and the importance of resources, because of that the average score of three (3) is a sufficient incentive for the construction of sports and recreational trails and the necessary infrastructure. 


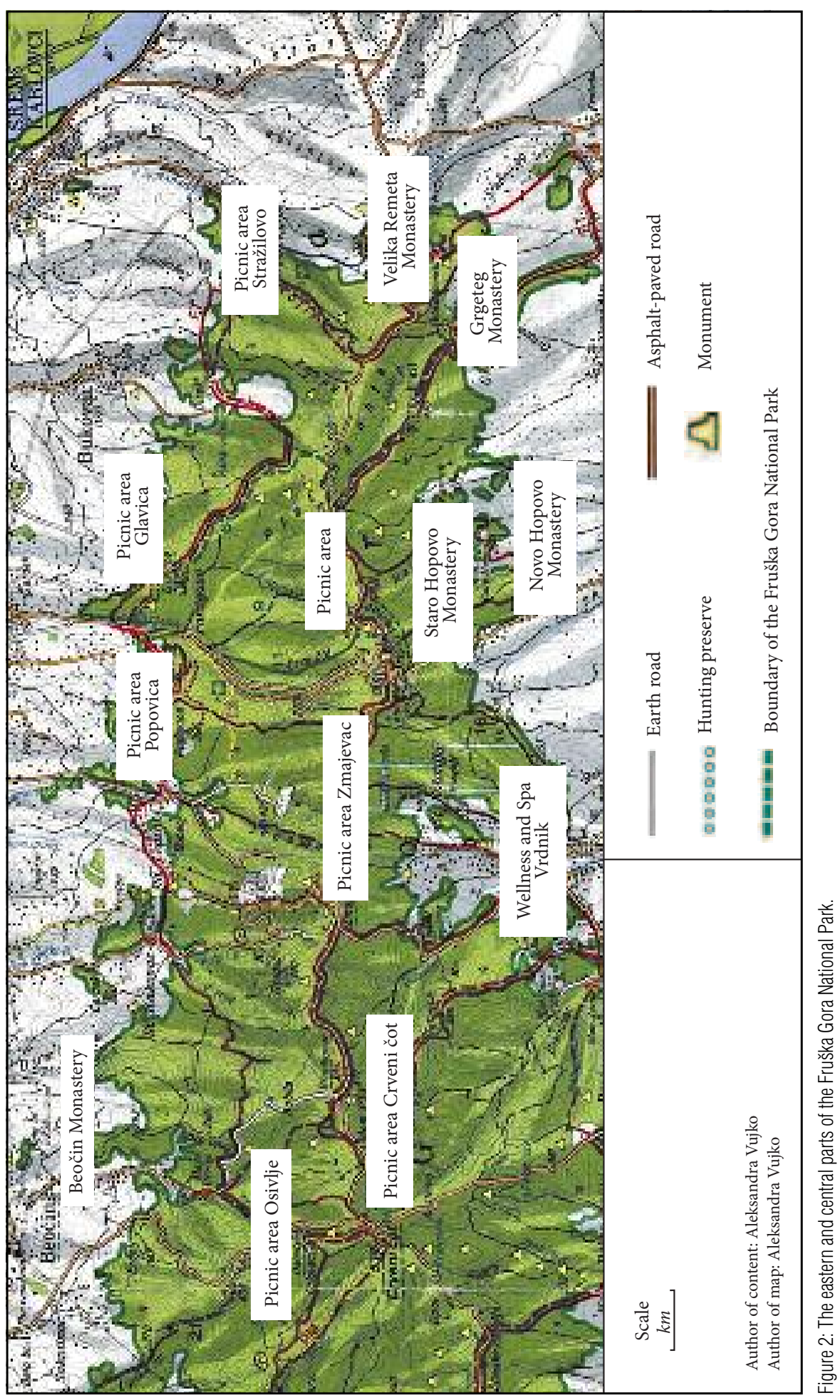


Aleksandra Vujko, Jovan Plavša, Evaluation of Fruška Gora National Park (Serbia) for sport and recreational tourism

Table 4: Evaluation of picnic areas for the sport and recreational tourism on the Fruška Gora National Park by the qualitative-quantitative method (Vujko 2011).

\begin{tabular}{|c|c|c|c|c|c|c|c|}
\hline & $\begin{array}{l}\text { Accessibility } \\
\text { of the resources }\end{array}$ & $\begin{array}{l}\text { Travel } \\
\text { equipmen }\end{array}$ & Environment & $\begin{array}{l}\text { The specificity } \\
\text { of resources }\end{array}$ & $\begin{array}{c}\text { The importance } \\
\text { of resources }\end{array}$ & Art value/ & $\begin{array}{l}\text { The average } \\
\text { value/ }\end{array}$ \\
\hline Stražilovo & $\begin{array}{l}3 \\
5\end{array}$ & $\begin{array}{l}3 \\
3\end{array}$ & $\begin{array}{l}4 \\
5\end{array}$ & $\begin{array}{l}3 \\
3\end{array}$ & $\begin{array}{l}4 \\
4\end{array}$ & $\begin{array}{l}5 \\
5\end{array}$ & 4 \\
\hline Iriški venac & $\begin{array}{l}3 \\
5 \\
\end{array}$ & $\begin{array}{l}2 \\
2 \\
\end{array}$ & $\begin{array}{l}4 \\
5 \\
\end{array}$ & $\begin{array}{l}4 \\
3 \\
\end{array}$ & $\begin{array}{l}4 \\
3 \\
\end{array}$ & $\begin{array}{l}2 \\
2\end{array}$ & 3 \\
\hline Zmajevac & $\begin{array}{l}3 \\
3 \\
\end{array}$ & $\begin{array}{l}2 \\
2 \\
\end{array}$ & $\begin{array}{l}4 \\
5 \\
\end{array}$ & $\begin{array}{l}4 \\
4 \\
\end{array}$ & $\begin{array}{l}4 \\
4 \\
\end{array}$ & $\begin{array}{l}2 \\
2 \\
\end{array}$ & 3 \\
\hline Popovica & $\begin{array}{l}2 \\
5 \\
\end{array}$ & $\begin{array}{l}1 \\
2 \\
\end{array}$ & $\begin{array}{l}4 \\
5 \\
\end{array}$ & $\begin{array}{l}3 \\
4 \\
\end{array}$ & $\begin{array}{l}3 \\
4 \\
\end{array}$ & $\begin{array}{l}2 \\
1 \\
\end{array}$ & 3 \\
\hline Glavica & $\begin{array}{l}2 \\
2 \\
\end{array}$ & $\begin{array}{l}1 \\
1 \\
\end{array}$ & $\begin{array}{l}3 \\
5 \\
\end{array}$ & $\begin{array}{l}2 \\
5 \\
\end{array}$ & $\begin{array}{l}3 \\
5 \\
\end{array}$ & $\begin{array}{l}1 \\
1 \\
\end{array}$ & 3 \\
\hline Osovlje & $\begin{array}{l}2 \\
2 \\
\end{array}$ & $\begin{array}{l}2 \\
2 \\
\end{array}$ & $\begin{array}{l}4 \\
5 \\
\end{array}$ & $\begin{array}{l}3 \\
5 \\
\end{array}$ & $\begin{array}{l}4 \\
5 \\
\end{array}$ & $\begin{array}{l}2 \\
1 \\
\end{array}$ & 3 \\
\hline Testera & $\begin{array}{l}2 \\
2 \\
\end{array}$ & $\begin{array}{l}2 \\
2 \\
\end{array}$ & $\begin{array}{l}4 \\
5 \\
\end{array}$ & $\begin{array}{l}4 \\
5 \\
\end{array}$ & $\begin{array}{l}4 \\
4 \\
\end{array}$ & $\begin{array}{l}2 \\
2 \\
\end{array}$ & 3 \\
\hline Andrevlje & $\begin{array}{l}2 \\
2 \\
\end{array}$ & $\begin{array}{l}2 \\
2 \\
\end{array}$ & $\begin{array}{l}4 \\
5 \\
\end{array}$ & $\begin{array}{l}4 \\
5 \\
\end{array}$ & $\begin{array}{l}4 \\
4 \\
\end{array}$ & $\begin{array}{l}2 \\
1 \\
\end{array}$ & 3 \\
\hline Koruška & $\begin{array}{l}2 \\
2 \\
\end{array}$ & $\begin{array}{l}1 \\
1 \\
\end{array}$ & $\begin{array}{l}3 \\
4 \\
\end{array}$ & $\begin{array}{l}3 \\
4 \\
\end{array}$ & $\begin{array}{l}4 \\
4 \\
\end{array}$ & $\begin{array}{l}2 \\
1\end{array}$ & 3 \\
\hline Letenka & $\begin{array}{l}3 \\
3 \\
\end{array}$ & $\begin{array}{l}2 \\
2 \\
\end{array}$ & $\begin{array}{l}4 \\
4 \\
\end{array}$ & $\begin{array}{l}4 \\
4 \\
\end{array}$ & $\begin{array}{l}4 \\
4 \\
\end{array}$ & $\begin{array}{l}2 \\
1 \\
\end{array}$ & 3 \\
\hline Lake/ Jezero Sot & $\begin{array}{l}3 \\
4 \\
\end{array}$ & $\begin{array}{l}1 \\
1 \\
\end{array}$ & $\begin{array}{l}4 \\
4 \\
\end{array}$ & $\begin{array}{l}4 \\
4 \\
\end{array}$ & $\begin{array}{l}4 \\
5 \\
\end{array}$ & $\begin{array}{l}2 \\
1 \\
\end{array}$ & 3 \\
\hline Lake/ Jezero Bruja & $\begin{array}{l}3 \\
2 \\
\end{array}$ & $\begin{array}{l}2 \\
1 \\
\end{array}$ & $\begin{array}{l}4 \\
4 \\
\end{array}$ & $\begin{array}{l}4 \\
4 \\
\end{array}$ & $\begin{array}{l}4 \\
4 \\
\end{array}$ & $\begin{array}{l}2 \\
1 \\
\end{array}$ & 3 \\
\hline Lake/ Jezero Moharač & $\begin{array}{l}2 \\
5\end{array}$ & $\begin{array}{l}1 \\
1\end{array}$ & $\begin{array}{l}3 \\
4 \\
\end{array}$ & $\begin{array}{l}3 \\
4 \\
\end{array}$ & $\begin{array}{l}4 \\
4 \\
\end{array}$ & $\begin{array}{l}1 \\
1\end{array}$ & 3 \\
\hline Dumbovački waterfall/slap & $\begin{array}{l}1 \\
1 \\
\end{array}$ & $\begin{array}{l}1 \\
1 \\
\end{array}$ & $\begin{array}{l}4 \\
4 \\
\end{array}$ & $\begin{array}{l}4 \\
4 \\
\end{array}$ & $\begin{array}{l}4 \\
4 \\
\end{array}$ & $\begin{array}{l}1 \\
1 \\
\end{array}$ & 3 \\
\hline Sviloški waterfall /slap & $\begin{array}{l}1 \\
1 \\
\end{array}$ & $\begin{array}{l}1 \\
1 \\
\end{array}$ & $\begin{array}{l}4 \\
5 \\
\end{array}$ & $\begin{array}{l}4 \\
5 \\
\end{array}$ & $\begin{array}{l}4 \\
5 \\
\end{array}$ & $\begin{array}{l}1 \\
1 \\
\end{array}$ & 3 \\
\hline Dobri waterfall/slap & $\begin{array}{l}1 \\
1\end{array}$ & $\begin{array}{l}1 \\
1\end{array}$ & $\begin{array}{l}4 \\
5\end{array}$ & $\begin{array}{l}4 \\
5\end{array}$ & $\begin{array}{l}4 \\
5\end{array}$ & $\begin{array}{l}1 \\
1\end{array}$ & 3 \\
\hline
\end{tabular}

Anthropogenic features of the Fruška Gora National Park are numerous. As a specific group of buildings, monasteries are presented. They could be better connected to each other in order to attract more visitors. Currently many cyclists and hikers, sport and recreational tourists who are not Orthodox Christians and would like to enter a sanctuary as a cultural landmark may have problems to enter the monasteries. It is certain that the landscaping and trail markings largely contributed to the popularization of the area and certainly can lead more visitors to holy sites in Fruška Gora (Stamenković and Plavša 2009).

As well as picnic grounds, most of the monasteries have low accessibility, therefore the lowest rating was assigned to the existing conditions of roads and tourist signalling, as well as for accessibility and infrastructure to the resources, i.e. tourist facilities in that area.

On the other hand, the environment, specific resources, the importance of resources and artistic value were assigned the highest marks. Thus the evaluation might help the monasteries to observe the necessity of being included in the sport and recreational tourism offer of the Fruška Gora National Park in the future.

As the previous method gave only a general condition of individual sites in Fruška Gora, it was necessary to pass to the method of Hilary du Cros and Olga Hadžić with associates. As for the recognition part, it is important to note that natural resources that are widely recognized also have higher level of tourist attraction. If this is applied to sport and recreational tourism on the Mountain, then it would involve creating 


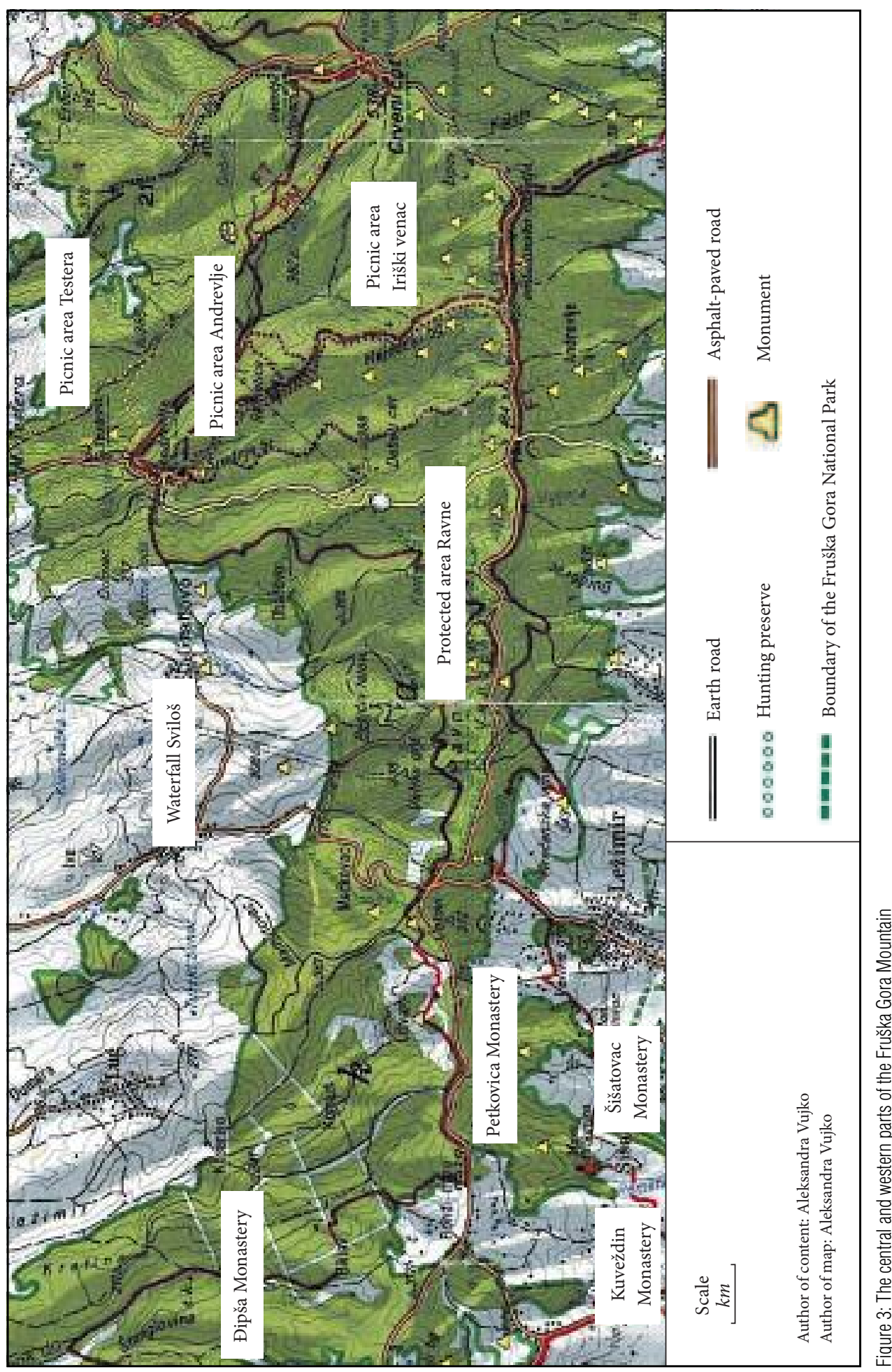




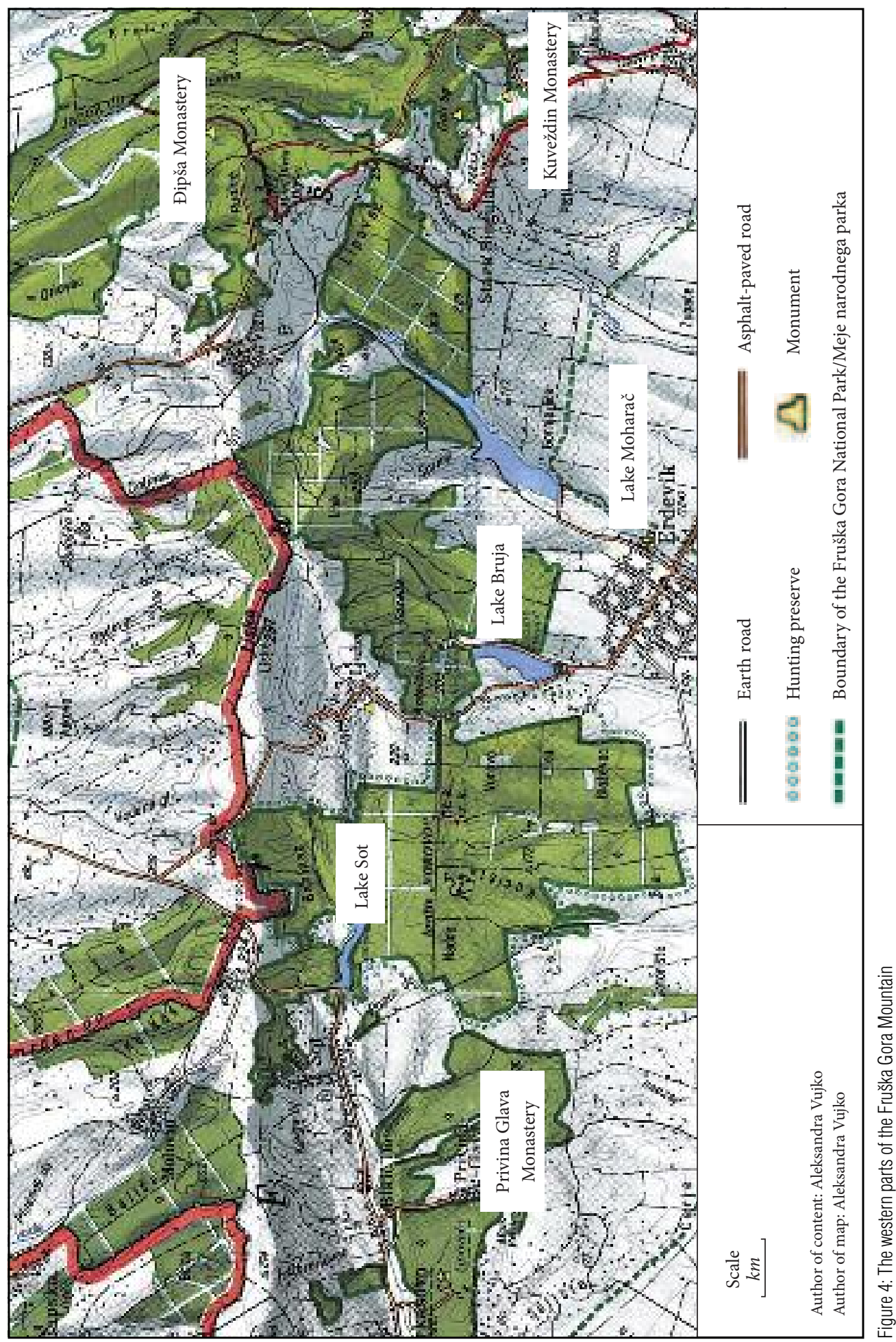


Table 5: Evaluation of monasteries for the sport and recreational tourism on the Fruška Gora National Park by the qualitative-quantitative method/Valorizacija samostana s kvalitativno in kvantitativno metodo (Vujko ... 2011)

\begin{tabular}{|c|c|c|c|c|c|c|c|}
\hline & Infrastructure & Facilities & Environment & $\begin{array}{l}\text { The specificity } \\
\text { of resources }\end{array}$ & $\begin{array}{c}\text { The importance } \\
\text { of resources }\end{array}$ & Art value & $\begin{array}{c}\text { The average } \\
\text { value }\end{array}$ \\
\hline Krušedol & $\begin{array}{l}3 \\
4\end{array}$ & $\begin{array}{l}3 \\
3\end{array}$ & $\begin{array}{l}4 \\
5\end{array}$ & $\begin{array}{l}4 \\
5\end{array}$ & $\begin{array}{l}4 \\
5\end{array}$ & $\begin{array}{l}5 \\
5\end{array}$ & 4 \\
\hline Petkovica & $\begin{array}{l}1 \\
1\end{array}$ & $\begin{array}{l}2 \\
2\end{array}$ & $\begin{array}{l}3 \\
5\end{array}$ & $\begin{array}{l}3 \\
5\end{array}$ & $\begin{array}{l}3 \\
5\end{array}$ & $\begin{array}{l}3 \\
5\end{array}$ & 3 \\
\hline Rakovac & $\begin{array}{l}3 \\
5\end{array}$ & $\begin{array}{l}2 \\
2\end{array}$ & $\begin{array}{l}3 \\
5\end{array}$ & $\begin{array}{l}3 \\
5\end{array}$ & $\begin{array}{l}3 \\
5\end{array}$ & $\begin{array}{l}4 \\
5\end{array}$ & 4 \\
\hline V. Remeta & $\begin{array}{l}3 \\
3\end{array}$ & $\begin{array}{l}3 \\
3\end{array}$ & $\begin{array}{l}3 \\
5\end{array}$ & $\begin{array}{l}3 \\
5\end{array}$ & $\begin{array}{l}4 \\
5\end{array}$ & $\begin{array}{l}4 \\
5\end{array}$ & 4 \\
\hline Đipša & $\begin{array}{l}2 \\
2 \\
\end{array}$ & $\begin{array}{l}1 \\
1 \\
\end{array}$ & $\begin{array}{l}3 \\
5 \\
\end{array}$ & $\begin{array}{l}3 \\
5 \\
\end{array}$ & $\begin{array}{l}4 \\
5 \\
\end{array}$ & $\begin{array}{l}4 \\
5 \\
\end{array}$ & 3 \\
\hline N. Hopovo & $\begin{array}{l}3 \\
3\end{array}$ & $\begin{array}{l}2 \\
2\end{array}$ & $\begin{array}{l}3 \\
5 \\
\end{array}$ & $\begin{array}{l}3 \\
5\end{array}$ & $\begin{array}{l}3 \\
5\end{array}$ & $\begin{array}{l}4 \\
5\end{array}$ & 4 \\
\hline St. Hopovo & $\begin{array}{l}1 \\
1\end{array}$ & $\begin{array}{l}1 \\
1\end{array}$ & $\begin{array}{l}3 \\
5\end{array}$ & $\begin{array}{l}3 \\
5\end{array}$ & $\begin{array}{l}3 \\
5\end{array}$ & $\begin{array}{l}4 \\
5 \\
\end{array}$ & 3 \\
\hline Jazak & $\begin{array}{l}3 \\
4\end{array}$ & $\begin{array}{l}3 \\
3\end{array}$ & $\begin{array}{l}3 \\
5\end{array}$ & $\begin{array}{l}3 \\
5\end{array}$ & $\begin{array}{l}3 \\
5\end{array}$ & $\begin{array}{l}4 \\
5\end{array}$ & 4 \\
\hline M. Remeta & $\begin{array}{l}3 \\
3\end{array}$ & $\begin{array}{l}3 \\
3\end{array}$ & $\begin{array}{l}4 \\
5\end{array}$ & $\begin{array}{l}3 \\
5\end{array}$ & $\begin{array}{l}3 \\
5\end{array}$ & $\begin{array}{l}4 \\
5\end{array}$ & 4 \\
\hline Grgeteg & $\begin{array}{l}3 \\
3 \\
\end{array}$ & $\begin{array}{l}3 \\
3 \\
\end{array}$ & $\begin{array}{l}3 \\
5 \\
\end{array}$ & $\begin{array}{l}3 \\
5 \\
\end{array}$ & $\begin{array}{l}4 \\
5 \\
\end{array}$ & $\begin{array}{l}4 \\
5 \\
\end{array}$ & 4 \\
\hline Beočin & $\begin{array}{l}3 \\
3 \\
\end{array}$ & $\begin{array}{l}2 \\
3 \\
\end{array}$ & $\begin{array}{l}4 \\
5 \\
\end{array}$ & $\begin{array}{l}3 \\
5 \\
\end{array}$ & $\begin{array}{l}3 \\
5 \\
\end{array}$ & $\begin{array}{l}4 \\
5 \\
\end{array}$ & 4 \\
\hline Privina Glava & $\begin{array}{l}3 \\
2\end{array}$ & $\begin{array}{l}3 \\
3\end{array}$ & $\begin{array}{l}4 \\
5\end{array}$ & $\begin{array}{l}4 \\
5\end{array}$ & $\begin{array}{l}4 \\
5\end{array}$ & $\begin{array}{l}4 \\
5\end{array}$ & 4 \\
\hline Šišatovac & $\begin{array}{l}3 \\
2\end{array}$ & $\begin{array}{l}2 \\
3\end{array}$ & $\begin{array}{l}3 \\
5\end{array}$ & $\begin{array}{l}4 \\
5\end{array}$ & $\begin{array}{l}4 \\
5\end{array}$ & $\begin{array}{l}4 \\
5\end{array}$ & 4 \\
\hline Kuveždin & $\begin{array}{l}2 \\
1\end{array}$ & $\begin{array}{l}1 \\
1\end{array}$ & $\begin{array}{l}3 \\
5\end{array}$ & $\begin{array}{l}3 \\
5\end{array}$ & $\begin{array}{l}4 \\
5\end{array}$ & $\begin{array}{l}4 \\
5\end{array}$ & 3 \\
\hline Vrdnik & $\begin{array}{l}4 \\
5\end{array}$ & $\begin{array}{l}3 \\
3\end{array}$ & $\begin{array}{l}4 \\
5\end{array}$ & $\begin{array}{l}3 \\
5\end{array}$ & $\begin{array}{l}4 \\
5\end{array}$ & $\begin{array}{l}4 \\
5\end{array}$ & 4 \\
\hline
\end{tabular}

Table 6: Elements related to the attraction of Fruška Gora National Park and factors of importance for the programming of sport and recreational tourism as atourism product of the Mountain - a method Hilary du Cros and Olga Hadžić et al (Vujko ... 2011)

\begin{tabular}{lcc}
\hline Elements & Fruška Gora & Total \\
\hline The degree of recognition & 3 & 3 \\
\hline Evocative component & 2 & 5 \\
\hline The attraction of the natural resource for special needs & 5 & 5 \\
\hline The existence of complementary natural and cultural resources & 5 & 5 \\
\hline Access to natural area & 5 & 5 \\
\hline Distance natural resource & 5 & 5 \\
\hline Service benefits & 5 & \\
& 5 & 2 \\
\hline
\end{tabular}


a well-recognized brand by which the Mountain would be recognized as a sports and recreation destination, which would certainly increase the degree of its attraction. As it can be seen from Table 6, the current condition of Fruška Gora as a recognisable route for sport and recreational tourism is actually very low. This is confirmed by the fact that there are almost no signs of modern sport and recreational tourism in the area.

Bearing in mind the proximity of Fruška Gora to the "The Danube route « which is one of the most important Europe cycle transversal (Vujko and Plavša 2010; www.gtz.de; www.dunavskastrategija.rs; www.ciklonaut.com), it is clear to what extent these data should be useful for the development of sport and recreational tourism in Fruška Gora and all the other interesting destinations and sites in Serbia (Pereira et al. 2007; Comanescu et al. 2009; Hadžić et al. 2010).

Table 7: Elements related to the management of Fruška Gora National Park - method Hilary du Cros and Olga Hadžić etal. (Vujko ... 011)

\begin{tabular}{lcc}
\hline Elements & Fruška Gora & Total \\
\hline The degree of recognition & 5 & 5 \\
\hline The influence of the natural resource to the social development of local communities & 5 & 5 \\
\hline Educational and scientific importance & 5 & 4 \\
\hline Rare natural resource & 4 & 3 \\
\hline Representativeness of the destination & 3 & 3 \\
\hline The sensitivity of the natural resource/ & 3 & 2 \\
\hline Natural resource management and regular monitoring & 3 \\
\hline Possibility of negative impact of a large number of visitors & 2 \\
\end{tabular}

Proper management of Fruška Gora is an important aspect of development of sport and recreational tourism and it is essential for sustainable tourism, which includes the preservation of the mountain for future generations (Pereira et al. 2007; Comanescu et al. 2009; Hadžić et al. 2010).

\section{Conclusion}

Since tourism development can be viewed as a planned, conscious and continuous activity, then the development of tourism on Fruška Gora Mountain is nothing more than the guidance for spatial distribution of relevant investment or corresponding spatial structure in which or with which sport and recreational tourism will develop on Fruška Gora National Park. Modern tourism development approaches the economic and social planning.

The present level of development of tourist infrastructure networks and recreational and other facilities on Fruška Gora Mountain is not in accordance with the possibilities that this mountain offers. The existing programmes and facilities do not provide developed forms of tourism supply. Unfortunately, this leads to the conclusion that, generally speaking, the current promotion of Fruška Gora Mountain is not present well (Ahmetović - Tomka 1995; Lazić 2004; Vujko and Plavša 2010; Vujko 2011; Vujko 2012).

The Fruška Gora National Park is an area in which there are three levels of protection (PPPN 2003). On the basis of the document it can be seen that the second and third zones, with regard to territory are the areas where it is desirable to develop sports and recreational tourism. In areas with other levels of protection any changes are prohibited (Ahmetović - Tomka 1995; PPPN 2003; Vujko and Plavša 2010).

The Fruška Gora National Park has many potential paths, most of them currently unmarked, along which there are many natural and cultural sites of outstanding importance. Evaluation and tourist activation could contribute to development of many other places for sport and recreational tourism in Serbia. 
We came to the conclusion that one of the main measures to achieve the quality of supply was exactly the standardization of services. Standardization in this context would involve the application of a designed system of standards for improving supply of primarily intended for sports and recreation tourists. Standardization of services would require multiple levels of service, and one of the first actions would be to categorize accommodation facilities, but such categorization that would indicate that a particular method is adapted to a particular object for cyclo-tourists and other sports and recreational tourist.

Analysis of some of the benefits of sport and recreational tourism in Fruška Gora show that in the future theme of health (Standeven and De Knop 1999; Plavša; Hayward; Hudson; Buckley 2006; Weed 2008; Vujko and Plavša 2010; Vujko 2011, Vujko, 2012), in conjunction with sustainable development could be one of the strongest supports for the development of sport and recreational tourism.

Its potential should be located very precisely and find a place in sustainable development for the opportunities, otherwise, their future is uncertain and is often used instead of their benefits could potentially become a threat (Downward 2005).

\section{References}

Ahmetović - Tomka, D. 1995: Turizam u zaštićenoj prirodi-marketing koncepcija. Novi Sad.

Bukurov, B. 1978: Bačka, Banat, Srem. Novi Sad.

Cutumisu, N., Cottrell, S. 2004: Images of a sustainable tourism development strategy in WWF Pan Parks: Comparison between a Swedish and Romanian National Park 1-1.

Comanescu, L., Nedelea, A., Dobre, R. 2009: Inventoring and evaluation of geomorphosites in the Bucegi Mountains. Forum geografic 8.

Buckley R. 2006: Adventure tourism. Wallingford.

Čomić, Đ., Pjevač, N. 1997: Turistička geografija. Beograd.

Ćurčić, N., Bjeljac, Ž. 2007: Turistička valorizacija manifestacije slaninijada u Kačarevu. Turizam 11.

Dragutinović, Z. 2000: Turistička prezentacija geo-nasleđa Fruške gore. Diploma thesis. University of Novi Sad University of Novi Sad, Department of geography, tourism and hotel management. Novi Sad.

Đurđev, S. B., Arsenović, D., Dragin, A. 2010: Contemporary problems in studying population of Vojvodina Province. Acta geographica Slovenica 50-1. DOI: http://dx.doi.org/10.3986/AGS50105

Downward, P. 2005: Critical (realist) reflection on policy and management research in sport,tourism and sports tourism. European sport management quarterly 5-3.

Du Cros, H. 2001: A new model to assist in planning for sustainable cultural heritage tourism. International journal of tourism research 3. DOI: http://dx.doi.org/10.1002/jtr.297

Erhartič, B. 2010: Geomorphosite assesstment. Acta geographica Slovenica 50-2. DOI: http://dx.doi.org/ 10.3986/AGS50206

Hadžić, O., Marković, B. S., Vasiljević, Đ., Nedeljković, M. 2010: A dynamical model for assessingtourism market atractiveness of a geos. »Geotrends 2010«. Novi Sad.

Hayward, P. 2002: Leisure and Tourism. Oxford

Hudson, S. 2003: Sport and adventure tourism. Binghamton.

Internet 1: www.gtz.de (3.5.2011.).

Internet 2: www.dunavskastrategija.rs (3.5.2011.).

Internet 3: www.ciklonaut.com (3.5.2011.).

Jovičić, Ž. 1962: Geografske osnove za razvoj turizma na Fruškoj gori. Novi Sad.

Lazić, L. 2004: Fruška gora national park. Tourism 8-1.

Milić, Č. 1973: Fruška Gora - geomorfološka proučavanja. Novi Sad

Obradović, S. 2006: Valorizacija nacionalnog parka »Fruška Gora« i održivi razvoj. M. Sc. thesis. University of Novi Sad, Department of geography, tourism and hotel management. Novi Sad.

Papadimitrou, D., Gibson, H. 2008: Benefits sought and realized by active mountain sport tourists in Epirus, Greece: Pre-and post-trip analysis. Journal of Sport and tourism 13. DOI: http://dx.doi.org/10.1080/ 14775080801972056

Pereira, P., Pereira, D., Caetano Alves, M. I. 2007: Geomorphosite assessment in Montesinho natural park (Portugal). Geographica Helvetica 3. 
Pralong, J.P. 2005: A method for assessing tourist potential and use of geomorphological sites. Géomorphologie: relief, processus, environnement 3 .

Reynard, E., Fontana, G. 2007: A method for assessing »scientific« and »additional values« of geomorphosites. Geographica Helvetica 3.

Petković, K., Čučulić - Trifunović, M., Pašić, M., Rakić, M. 1976: Fruška Gora - monografski prikaz građe i tektonskog sklopa. Novi Sad.

Plavša, J. 2007: Sportsko-rekreativni turizam. University of Novi Sad, Department of geography, tourism and hotel management. Novi Sad.

Spatial plan of special purpose of Fruška gora by 2022. Institute for Nature Conservation of Serbia, 2003. Novi Sad.

Stamenković, I., Plavša, J. 2009: The new age of faith tourism and Fruška Gora Mountain (Serbia). Turizam 13-2.

Standeven, J., Knop, P. 1999: Sport and recreational tourism. Champaign.

Simonsen, S. P., Jorgensen, B., Robbins, D. 1998: Cycling tourism. Bornholm.

Stanković, M. S. 1994: Turistička geografija. Beograd.

Serrano, E., González-Trueba, J. J. 2005: Assessment of geomorphosites in natural protected areas: the Picos de Europa National Park (Spain). Géomorphologie: relief, processus, environnement 3.

Vujko, A., Tomka, D. 2009: How to overcome difficulties in the creating of adequate supply for cyclingtourism in the Mountains of Vojvodina-SWOT analysis. Zbornik radova 2.

Vujko, A., Plavša, J. 2010: Networking of Fruška Gora lakes tourist offer through system of cyclepaths case study Sot, Bruje and Moharač. Turizam 15-1.

Vujko, A. 2011: Fruška Gora i Vršačke planine - sadašnje i buduće destinacije sportsko-rekreativnog turizma. Ph. D. thesis. University of Novi Sad, Prirodno-metematički fakultet, Departman za geografiju, turizam i hotelijerstvo. Novi Sad.

Vujko, A. 2012: Pozitivni aspekti razvoja biciklističkog turizma na turističkim destinacijama - studija slučaja Fruška Gora. Tims acta 6.

Weed M. 2008: Sport and recreational tourism experience. Journal of sport and tourism 13-1. 